\title{
An assessment of the impact of tourism globalization in Africa
}

\author{
Thomas P. Z. Mpofu' ${ }^{1}$
}

\begin{abstract}
The tourism sector is one of one of the exemplars of the phenomenon of globalization. This is due to the geographical scale of the industry, increased spatial linkages between places and people from different locations. The purpose of this paper was to evaluate the extent to which tourism globalization had impacted on African countries. The paper submits that some African countries have indeed increased their revenues and foreign currency earnings, created employment, brought new technology, and improved their tourism facilities and services to meet international standards. Globalization has created respect for African cultures and contributed to the protection of historical monuments and natural environments. The paper notes the role of technological improvements in transportation and telecommunications in making global travel shrink in terms of time and distance. However, the paper notes that globalization has also brought negative impacts to Africa. These include financial leakages, price increases, and a change in some African cultural values. The paper concludes that the world is in the era of globalization and that the phenomenon is here to stay. Therefore, the paper recommends that Africa should closely monitor the negative impacts of globalization while continuing to reap the benefits that accrue from tourism globalization.
\end{abstract}

Key words: globalization, spatial linkages, multinational corporations, vertical and horizontal mergers.

\section{Introduction}

Although the term globalization has now been in use for several years, its contemporary connotation is rooted in the study of international relations (Burns and Holden, 1995; Youell, 1998). The word now cuts across the entire spectrum of academic 'tribalism' as it is being defined differently by different scholars, depending on their subject perspectives. A geographical

\footnotetext{
${ }^{1} \mathrm{PhD}$ (Assistant Professor) under the Urban Management Masters Program, a World Bank-funded Capacity Building Program, Ethiopian Civil Service College, Addis-Ababa. Contacts: mpofutpz@yahoo.co.uk, or tpz.zuluboy@gmail.com.
} 
perspective of the term has been presented by Short and Kim (1999) and Shaw and Williams (2002). The former see globalization as the stretching of activities across the globe while the latter regard the globalization phenomenon as a spatial widening of the linkages between places, leading to the internationalization of cultures, more global flows of products and services and increased competition. Thus globalization has become a process that renders various activities and aspirations worldwide in scope.

Globalization has also become an umbrella term used for a complex series of economic, social, technological, cultural and political changes that are seen as increasing interdependence, integration and interaction between people and companies in different locations. In particular, it is due to the increase in worldwide business and trade between multinational and transnational corporations, among others, irrespective of their geographical locations, that the term has gained prominence (Cooper et al, 1998). It is these inherent characteristics of globalization that have precipitated national boundaries to be more fluid or porous with respect to the movement of people and services.

\section{Globalization and the tourism industry}

The geographical widening of linkages between places has become a major factor in the development of international tourism, leading to the internationalization of tourism, leisure 'culture', more global flows of tourists, and increased competition (Tribe, 1997; Youell, 1998). Through the process of intensification, the long-established trickles of tourists to the most distant corners of the globe have been transformed into large scale tourist flows (Waters, 1995). Shaw and Williams (2002) have added that tourism is, in many ways, one of the most powerful exemplars of globalization as the geographical scale of travel and trade has become greater than it used to be, with spatial interactions taking place over greater distances and ever wider circles. Thus the globalization phenomenon has contributed significantly to the spread of tourists to the furthest reaches of the planet, including Africa, leading to the shrinking of the "pleasure 
periphery" as it trends, in its most innocuous sense, towards a single world society (Bayly et al, 2004; Bhatia, 2006).

As observed by Cochrane and Pain (2000), due to globalization, there is increasing host-guest interaction as apparently distant cultures and societies potentially come face to face with each other at local level. Hence Waters (1995) observed that globalization is the stretched social relations in terms of the existence of cultural, economic, political, social and technological networks of connections across the world; the increased density of interactions across the globe; and the increased interactions between states which share common borders. As a consequence and to a very large extent, many travelers now conceptualize the world as a single place, leading to increased density of interactions and willingness by many people to travel to tourism destinations in Africa.

\section{Factors facilitating globalization of the tourism industry}

A number of factors have played a major role in facilitating globalization in general and international tourism in particular. These include the increase in worldwide business and trade, technological developments in transport and communications, increased cultural and political interdependence, and the role of multinational and transnational corporations.

\section{International Trade}

The globalization of the world economy has played a critical role in bringing about changes in business tourism. As trade and foreign direct investments require travel abroad, they have undoubtedly contributed to the further globalization and growth of the business tourism industry. According to the World Tourism Organization (WTO) (1983), the growth of international tourism and the increased movement of tourists have been fundamentally facilitated by shift to free markets. To this, Microsoft Encarta (2000) added that the removal of trade barriers had also facilitated business tourism.

\section{Technological Improvements}


One of the often cited drivers of globalization is the improvement in new technology. Improvements in transport and communications have fundamentally facilitated the growth and movement of international tourists. According to Shaw and Williams (2002), the process of globalization has significantly been advanced through technological developments in the fields of transport and communications, particularly long range aircrafts, the internet, computer reservations systems (CRS) and e-commerce. Microsoft Encarta (2000) also affirmed that a whole world of new opportunities for business and trade has been opened up by technological improvements in transport and communication systems as well as by internet banking.

Due to the exponential growth in air transport, global travel has shrunk in terms of time and distance, allowing tourists to travel to distant international destinations with ease [World Tourism Organization (WTO), 1983]. Hence Binns et al (1999) are of the view that tourism was now quintessentially linked to the phenomenon of time-space compression.

The deregulation of transport and trade around the world have also made business travel more competitive and allowed the emergence of budget airlines and cruise lines. According to Wikipedia.com (2006), these low cost carriers have facilitated travel and are the fastest growing trend in the tourism industry. Competition for terminal slots and space, for example, as well as the stage of maturity of the domestic travel industry, has thus created the need for air travel to be expanded and harmonized regionally and internationally (Cooper et al, 1998; Knowles et al, 2001).

According to Page (1999), information technology (IT) has particularly revolutionized the organization and management of tourist businesses. For example, the introduction of computer reservation systems (CRS) and global distribution systems (GDS) in particular, has assisted the globalization of the supply side of tourist services. Inkpen (1998) estimated that there were over half a million GDS terminals around the world, connecting most of the world's airlines to potential travelers. These include some of the largest terminals that allow travelers to choose their airline, check 
the time of flight, read the rules for travel and reserve their tickets online.

The internet is probably the most important development underpinning the process of globalization. According to Microsoft Encarta (2000), the internet has tended to make national boundaries invisible, thus extending the ability of potential travelers to reach out across the globe in search of new travel information and opportunities. Most of the international and regional agencies, airlines, hotels as well as many travel associations and public sector bodies all now have their own websites aimed at promoting tourism around the world. The purchase of Internet-based entertainment has also greatly facilitated the rapid global dispersal of new forms of leisure activities. This has reinforced the role of the increasingly global media in the social construction of desirable lifestyles (Page, 1998).

The advances in e-commerce have seen tourism products becoming some of the most traded items on the internet (Wilipodia.com, 2006), thus making it much easier to choose, book and pay for holidays from the comfort of one's home. Further more, in many parts of the world, including in Africa, credit cards can now be used to pay for any purchases online.

\section{Regionalization}

Tourism globalization has been facilitated by increased interconnections between states that border with each other. The spatial pattern of macro-regionalization is particularly distinctive in the two largest international tourism flows between the United States of America (USA) and Canada as well as the trans-Atlantic flows. In Western Europe, for example, regionalization has brought with it the promotion of the four 'freedoms", that is, the free movement of capital, people, goods and services which, along with the open skies policy, have allowed companies to expand their operations across international borders (Shaw and Williams, 2002). Sub-regional systems also exist between Europe and North Africa as well as between South Africa and most countries in Southern Africa (Jansen-Verbeke, 1995). 


\section{Role of Multinational Corporations}

Due to increased interconnections; the volatile and erratic nature of the international tourism demand; as well as the hypercompetition worldwide, the tourism industry has been characterized by the active involvement and dominant role played by multinational corporations (MNCs) and transnational corporations (TNCs). According to Page (2005), some international companies have taken advantage of globalization to seek for new opportunities to grow their enterprises, reap the benefits of the economies of scale, increase their market share, suppress competition, and achieve global dominance.

As a result, the world has witnessed a flurry of different MNC and TNC strategies such as vertical and horizontal alliances, mergers, acquisitions, as well as formal linkages. According to Burns and Holden (1995), vertical integration is a business practice whereby companies at different levels in the distribution chain seek to control various stages of production, delivery and marketing of their products. For example, some tour operators have grown from medium-sized national companies to truly international corporations that move millions of people around the globe each year (Burns and Holden, 1995; Cooper et al, 1998). Similarly, a number of tour operators today have their own aircrafts and hotels, while some airlines also offer chauffeur and car rental services (Demenech, 2006). Some global firms have also capitalized on these trends and produced standardized tourism products in order to contribute to the homogenization of the world tourism market.

Other business enterprises have sought to survive through horizontal integration whereby companies at the same level have sought mergers with companies at their level in the distribution chain (Youell, 1998). The mergers have been characterized by either two companies offering competing services; a result of a takeover of one company by another; or a voluntary agreement between two companies. Within the aviation industry, horizontal integration has resulted in some airlines expanding their operations into different countries. The British Airways, for 
example, have forged a trans-Atlantic alliance with American Airlines (Cooper et. al, 1998).

Horizontal integration has also been achieved through licensing and franchising. According to Knowles et al (2001), franchising is a contractual agreement whereby a firm allows another to sell products and provide services on its behalf for a fee. This is also evident in the tourism industry. According to Shaw and Williams (2002), this is the case with such brand names as the six corporate chains Choice, Best Western, Marriott, Sheraton, Hyatt, and Radisson of America, Holiday Inn, Forte, and Hilton of the United Kingdom, Accor and Club Mediterranee of France and Inter-Continental of Japan. To these one can add MacDonald's, Wimpy, Avis Rent-a-Car, etc.

\section{Country image}

Although tourists may vary in type, they all tend to be influenced by images of destinations and activities. The importance of image within tourism is such that the World Tourism Organization (1979, quoted by Cooper et al. 1993:25) have suggested that the term image embraces "the ideas, conceptions held individually or collectively of a destination". Thus 'destination image' has become so catholic and taken a wider currency that it is now taken to mean "the totality of beliefs and impressions that tourists, individually or collectively, have regarding each tourist destination. This is because tourism is a very sensitive phenomenon that involves the movement of people, not goods or commodities.

To boost the image of their countries, some governments have used MNCs to create good impressions about their countries. Incentives and tax concessions have been used to attract MNCs. This is because a country that is shunned by international investors is, consequently, shunned by tourists. Therefore, the presence of MNCs and other international organizations and embassies in a country tends to give a positive image of that country, thus helping to attract international visitors.

Positive impact of tourism globalization in Africa 
The phenomenon of tourism globalization ostentatiously flutters almost throughout Africa, as there are very few countries within this continent which have not been touched, in one way or another, by international tourism.

\section{Tourist Arrivals}

According to Reid (1999), of the total number of tourists that visited Africa in 1998, about 53.8\% of them came from outside the continent, particularly Europe, followed by North America and then East Asia. In part, this reflects the "discovery" of Africa by the tour companies, travel agencies and tourists from the developed world. For example, international arrivals to Africa increased from about 10 million in 1987, to 15 million in 1990, 20 million in 1996, 23.5 million in 1997, to about 27, 3 million in 1998 , an average growth rate of $6.8 \%$ per annum ((Hall and Page, 1999; WTO, 1999). This brought Africa's market share of world tourism arrivals to 4\% (WTO, 1999). In 2005, Africa recorded its highest ever growth of $10 \%$ in tourist arrivals.

At regional level, the Southern African Development Community (SADC) increased its international tourist arrivals from 12.4 million in 1999 to 15 million in 2005, an average annual growth rate of 6\% [Regional Tourism Organization of Southern Africa (RETOSA) Annual Reports, 2000-2005].

In 1996, Africa's leading tourist destinations were South Africa (4.64 million), Tunisia (3.89 million), Morocco (2.69 million), Zimbabwe (1.74 million), Kenya (0.907 million), Botswana (0.660 million), Mauritius (0.435 million), Namibia (0.405 million), Reunion (0.339 million) and Tanzania (0.326 million) (Reid, 1999). From 2000 to 2005, remarkable growth was recorded in Mozambique (37\%), Kenya (28\%), with South Africa and Mauritius recording 11\% each (UN WTO: Barometer, 2006). In Ethiopia, the numbers almost doubled from 103000 in 1995 to 210000 in 2004, and were expected to reach 227000 by 2005 (Tekle, 2001). Between May 2008 and May 2009, Ethiopia hosted 383,400 tourists. This was 25,000 more than the previous year (Zinabu, 2009, cited by The Ethiopian Herald, 12 July, 2009).

\section{Economic Impacts}


The increase in tourist arrivals generally pre-supposes a commensurate increase in positive economic, social, environmental and political impacts to the countries concerned. Table 1.0 below shows that, due to the increase in tourist arrivals in Africa, international tourism has been accompanied by significant increases in government revenues. As a consequence, tourism has become one of the main export activities within several African countries. For example, out of a world total of $\$ 8.7$ billion in international receipts, Africa grossed about $\$ 8.7$ billion. At country level, South Africa earned \$1.738 million, Tunisia \$1.436 million, Morocco \$1.292, Kenya \$0.493, Mauritius 40.473, Namibia \$0.265, Zimbabwe \$0.219, and Botswana \$0.178 million, in 1996 (Reid, 1999).

In Zimbabwe, revenue from international tourism increased by an average growth rate of $18 \%$ during the decade 1989 to 1999 [Zimbabwe Tourism Authority (ZTA), 2000]. In Ethiopia, international tourism was expected to account for $9.2 \%$ of the Gross Domestic Product (GDP) in 1999 (World Tourism Organization, 1999). Between May 2008 and May 2009, over 1.9 billion birr was earned from tourists who visited the country. This was partly attributed to the expansion of infrastructural facilities and the prevalence of peace in the country (The Ethiopian Herald, 12 July 2009).

Although the receipts accounted for less than $2 \%$ of the total global earnings, they contributed significantly to Africa's total export earnings, as they increased from 4.9\% in 1985 to $10.4 \%$ in 1993 (Reid, 1999). As a result of these positive impacts, international tourism is now viewed as a major source of revenue, especially by some cash-starved African countries. As observed by De Chavez (2003), because of its potential to generate much needed revenue, international tourism has also become one of the packages for debt servicing or bail outs for African countries in distress.

Table 1. Tourism receipts in Africa (US\$ 000)

\begin{tabular}{|l|r|r|r|r|r|}
\hline Region & \multicolumn{1}{|c|}{$\mathbf{1 9 8 8}$} & \multicolumn{1}{|c|}{$\mathbf{1 9 9 0}$} & \multicolumn{1}{|c|}{$\mathbf{1 9 9 2}$} & \multicolumn{1}{|c|}{$\mathbf{1 9 9 4}$} & \multicolumn{1}{c|}{$\mathbf{1 9 9 6}$} \\
\hline World & 202552 & 266207 & 310785 & 351079 & 425047 \\
\hline Africa & 4567 & 5333 & 6023 & 6511 & 7670 \\
\hline
\end{tabular}




\begin{tabular}{|l|r|r|r|r|r|}
\hline $\begin{array}{l}\text { East } \\
\text { Africa }\end{array}$ & 797 & 1116 & 1251 & 1404 & 1888 \\
\hline $\begin{array}{l}\text { Mid } \\
\text { Africa }\end{array}$ & 67 & 202 & 106 & 122 & 118 \\
\hline $\begin{array}{l}\text { North } \\
\text { Africa }\end{array}$ & 2458 & 2297 & 2515 & 2622 & 2751 \\
\hline $\begin{array}{l}\text { Southern } \\
\text { Africa }\end{array}$ & 745 & 1243 & 1515 & 1816 & 2238 \\
\hline $\begin{array}{l}\text { West } \\
\text { Africa }\end{array}$ & 500 & 575 & 637 & 547 & 675 \\
\hline
\end{tabular}

Source: Reid (1999)

According to the WTO (1981), the generation of foreign currency earnings; contribution to the balance of payments, increases in government revenues from taxation of multinational corporations, airline tickets and hotel rooms; a positive balance of payments; and the creation of much needed employment opportunities were the main positive economic impacts associated with the globalization of the tourism industry in Africa.

Table 2 below shows employment trends within the tourism sector, for most regions of the world, including Africa. The World Travel Tourism Council (WTTC) has estimated that there are about 321 million people in the world employed directly and indirectly in the tourism industry. This is about $10 \%$ of the world labor market force. Vellas and Becherel (1995) go on to say that there is more employment generated by international tourism in developing than in industrialized regions. This is because tourism is a labor intensive industry and developing countries are generally characterized by high unemployment. 
Table 2. Global estimates in employment in the tourism industry (1998 - 2010)

\begin{tabular}{|l|r|r|rr|r|}
\hline Region & \multicolumn{2}{|c|}{ GDP US\$ Billion } & \multicolumn{3}{c|}{ Jobs (Million) } \\
\hline & \multicolumn{1}{|c|}{$\mathbf{1 9 9 8}$} & \multicolumn{1}{c|}{$\mathbf{2 0 1 0}$} & $\mathbf{1 9 9 8}$ & \multicolumn{2}{|c|}{$\mathbf{2 0 1 0}$} \\
\hline World & 3564.3 & 8008.4 & 230.8 & 328.4 \\
\hline Africa & 48.0 & 137.7 & 16.3 & 23.1 \\
\hline North Africa & 23.5 & 72.1 & 3.0 & 4.2 \\
\hline $\begin{array}{l}\text { Sub-Sahara } \\
\text { Africa }\end{array}$ & 24.5 & 65.6 & & 13.3 & 18.9 \\
\hline
\end{tabular}

Source: McIntosh (2000)

Although employment data from most African country were hard to come by during the study period, statistics from Kenya, Zimbabwe and Ethiopia was used to illustrate the trends. In Kenya, about 7500 people were employed in hotels, 1300 as tour operators, 500 as safari out fitters, 100 in air charter, 500 in curio sales and 1600 by government and national parks (Harrison, 1992). In Zimbabwe, there was a gradual increase in tourism employment, from 16,000 in 1980 to 338,533 in 1999. Table 3 below shows employment trends in Zimbabwe, from 1992 to 2000. According to the World Tourism Organization (1999), in Ethiopia, international tourism was expected to account for 7.1\% of total employment during that year.

\section{Multiplier effects}

The worldwide hyper-competition brought about by globalization, has had additional multiplier effects in Africa. Many multinational and transnational companies have taken advantage of globalization to seek for new opportunities in Africa to grow their enterprises, increase their market share, and achieve global dominance. Others have forged vertical and horizontal alliances with companies in Africa, resulting in a wider choice of standardized products within Africa (Page, 2005).

The globalization of the tourism industry has also created new tourism attractions, markets for African products, as well as additional funds for new infrastructures such as water, roads, power, and telephones which, in turn, have also benefited local residents (Cooper et al, 1998). In a bid to remain viable in an environment of hyper-competition, tourism companies in Africa 
have also endeavored to provide high quality and standardized products and services in order to keep pace with international standards (Cooper et al, 1998; Burns and Holden, 2005).

Within the aviation industry, globalization has seen some international airlines expand their operations into different countries of Africa, while others have forged alliances with Ethiopian Airlines, Kenya Airlines, South African Airlines and others (Cooper et. al, 1998). Africa has also witnessed a number of travel agencies and tour operators move millions of travelers around the continent each year (Burns and Holden, 1995; Demenech, 2006).

In several African countries, horizontal integration has been achieved through contractual agreements with big brand names such as The Holiday Inns, Hilton Hotels, Sheraton, Intercontinental, MacDonald's, Avis Rent-a-Car, etc to sell products or provide services on their behalf for a fee. These global connections have greatly increased the stability of some African companies involved in the tourism industry. For example, some small hotels, food outlets and transport companies have managed to build linkages with larger international companies in order to attain financial backing and become more secure (Knowles et al, 2001). According to Burns and Holden (2005), this has made them less vulnerable to economic downturns.

Tourism globalization has also been effected through increased interconnections between states that border with each other. The regionalization of Southern Africa offers a good case. The establishment of the Southern African Development Community (SADC) has laid a promising basis for integrated economic development, including in the tourism industry. The subsequent creation of the Regional Tourism Organization of Southern Africa (RETOSA) has seen the tourism industry being coordinated, facilitated and promoted across common borders.

\section{Socio-cultural impacts}

By virtue of its basic element of cross-border travel, international tourism has become an essential medium for interaction and 
communication between Africa and different civilizations. This has helped to broaden the limits of knowledge and the sometimes conservative stereotypes and narrow values of people, particularly those living in peripheral regions of Africa. In this context, globalization has served as a prime vehicle for developing and improving African social and cultural understanding by being in contact with diverse travelers of the world.

Because tourism experiences, by their very nature, have to be enjoyed in situ, they of necessity involve a degree of host-guest interaction. This has sometimes created a better understanding and respect for the value of African cultures and norms; resulting in friendships being made between international travelers and their African hosts. It has also helped in developing indigenous African cultures, and contributed to the conservation of historical monuments and architectural buildings such as Amapungugwe in South Africa, the Great Zimbabwe in Zimbabwe, the pyramids in Egypt and the ancient town of Axum in Ethiopia, among many others.

International tourism has also helped to reduce and/or break down prejudices, barriers, suspicions and other stereotypes that exist among Africans themselves as well as between Africans and international tourists. Consequently, these positive demonstration effects, have, in turn, contributed to new gender and intergenerational relationships as well as the broadening of social horizons. Hence tourism has been cited by Shaw and Williams (2002) as an important medium of development across cultural and international boundaries, and a major contributor to international goodwill.

\section{Environmental impacts}

Tourism, given that it involves in situ experiences, has led to greater protection of and improvements to some unique landscapes such as the Victoria Falls and the Matopo balancing rocks in Zimbabwe, the Great East African Rift Valley, Mount Kilimanjaro and many others. Most of these have since been declared 'World Heritage Sites' under UNESCO. Ethiopia has 
eight such tourist sites on the UNESCO list, and is about to add two more.

\section{Improved image}

Because of the economic benefits that accrue from international tourism, some African governments have committed themselves to improving their image and positioning on the international stage. This is due to the realization that the growth of tourism has often been constrained by a negative image of Africa in international media, mainly focused on drought, famine, and wars; the state of tourist infrastructure and facilities; the relative high cost of airfares, car-hire and entrance fees.

To address the issue of image, some African governments have gone out of their way to attract MNCs, through incentives and tax concessions, to invest in their countries. Others have focused on expanding their tourism infrastructure, improving services provided by their hotels and tour operators, as well as access to their attractions. In Ethiopia, the state has committed itself to "improve Ethiopia's international image and positioning" and "establish an enabling environment" and "better investment incentives" (A Plan Accelerated and Sustained Development to End Poverty (PASDEP), 2006:57 and 58).

\section{Negative impacts of tourism in Africa}

Despite the many benefits that have so far accrued to African countries, the process of globalization has also been associated with a number of negative effects. These include the problem of financial leakages to pay for imports and other intermediaries, as well as the repatriation of foreign currency to mother countries of MNCs. Page (2005) estimated the average import-related leakage for most African countries to be between 40 and 50 per cent. He goes on to say that only $10 \%$ of gross earnings from tourism were retained within the country (Page, 2005). It is for this reason that, while Ethiopia is considering increasing the "volumes of tourists and levels of tourist spending", the country calls upon the tourism sector to "minimize foreign exchange leakages" (PASDEP, 2006:57). 
Some international travel companies often provide the entire package of services to the traveler, from planning of holidays and purchasing of tickets, right through to travel, accommodation, catering and local tours. This arrangement has enabled international tourists to spend only a small fraction of their money in the destination countries.

The globalization of the tourism globalization often leads to price increases of basic commodities as well as high land values. As a consequence, the availability of basic commodities has declined at the expense of "international" products, thus forcing local residents to travel long distances to buy basic commodities. Due to high land values, some local business people have been driven further away from the tourism core areas, a process referred to as the "displacement effect". According to Burns and Holden (2005), multinational corporations may even drive some locally-owned businesses completely out of business.

Third, the globalization of the tourism industry has tended to be characterized by expatriate labor. Generally, jobs in high positions are often reserved for expatriate employees while locals are employed in lowly paying and seasonal jobs. According to Parkins (2000), some foreign-owned companies usually build, own and manage their own tourist complexes, with little advantage to host countries.

From socio-cultural perspective, an influx of large numbers of international tourists into some parts of Africa has led to $\boldsymbol{a}$ change in cultural values, and not necessarily for the better. In some African countries, the socio-political dynamics of international tourism have resulted in the local community largely losing its cohesion as well as control over its own affairs. Practices such as prostitution, drug dealing, and black markets are among the often cited ills. This has negatively affected some African ways of life which involved a greater sense of community co-operation and a strong commitment to family life, religion and traditional customs. 
Environmentally, an influx of large numbers of tourists has tended to destroy the very ambience that attracts tourists in the first place. Unfortunately, many multinational corporations do not rank environmental protection among their priorities. As a consequence, the impacts of their operations are hardly monitored.

\section{Conclusion}

The conclusion of the paper is that the globalization of the tourism industry into a more global export product has brought many positive impacts to African countries. However, the impacts that accrue to each country depend upon its level of development; the degree of incorporation into the world economy; as well as the investment climate of each country.

To fully benefit from the positive impacts of globalization, the paper recommends that African countries need to improve their image on the world stage. It is critical to realize that tourism is a very sensitive sector that involves the movement of people, not goods or commodities. As such, most people will always consider their safety first before choosing a destination whose security is, from their point of view, suspect. This is a basic natural instinct of most human beings.

However, while striving to benefit from this growing industry, African countries need to closely monitor the negative economic, socio-cultural and environmental aspects of globalization. This way, Africa can have its cake and eat it, too!

\section{References}


Bhatia, A.K. 2006. International Tourism Management, Sterling Publishers, Pvt, Ltd, New Delhi.

Brunt, B. 1997. Western Europe: A Social and Economic Geography, Gill and MacMillan

Burns, P, Holden, A. 1995 Tourism: Anew Perspective, Prentice Hall, Hemel Hempstead, UK

Butler, R. 1980. The concept of tourism area cycle of evolution: implications for management of resources. Canadian Geographies.

Cooper, C. et al. 1998. Tourism: Principles and Practice, Pitman, London

David, D.B. 2001. Tourism in Least Developed Countries, Madrid, Spain.

Federal Democratic Republic of Ethiopia September 2006. A Plan Accelerated and Sustained Development to End Poverty (PASDEP). Addis Ababa, Ethiopia.

Gillmor, D. 1997. Western Europe: A Social and Economic Geography, Gill and Macmillan, Dublin.

Hall, C.M, Page, S. 1999. The Geography of Tourism and Recreation: Environment, Place and Space, Routledge, London.

Hunter, C, Green, C. 1995 Tourism and the Environment: A Sustainable Relationship? Routledge, London.

Jenner, P, Smith, C. 1992. The Tourism Industry and the Environment, EIU, London.

Medlik, S. 1972. Economic Importance of Tourism University of Surrey, Surrey. 
Mowforth, M, Munt, I. 1998. Tourism and Sustainability: New Tourism in the Third World Routledge, London.

Mpofu, T.P.Z. 2008. The Role of Tourism in Urban Renewal: Prospects and Opportunities for Addis-Ababa In van Dijk, M.Pand Fransen, J. (Eds) Managing Ethiopian Cities in an era of Rapid Urbanization, Erasmus University, Rottrdam.

Nagle, G. and Spencer, K. 1996. A Geography of the European Union: A Regional and Economic Perspective, Oxford, UK

Page, S.J. 1995. Urban Tourism, Routledge: London

Pattulo, P. 1996. Last Resorts: The Cost of Tourism in the Caribbean, Cassell, London.

Pearce, D. 1995, Tourism Today: A Geographical Analysis, Longman, Harlow, UK

Shaw, G, Williams, A.M. 2002 Critical Issues in Tourism: A Geographical Perspective, Blackwell Publishers, Oxford.

Swarbrooke, J, Horner, S. 1999 Consumer Behavior in Tourism, Oxford, Butterworth-Heinemann

Williams, A.M. 1995 Capital and the trans-nationalization of tourism. In A. Montanari and A.M. Williams (eds), European Tourism: Regions, Spaces and Restructuring, Wiley, Chichester.

World Tourism Organization, 2000a Tourism Highlights 2000, WTO, Madrid.

World Travel and Tourism Council 2006 Strategy, Development and Sustainable Tourism, Online at htt://www.wttc.travel/stratdev/sustainable.asp 
Youell, R. 1998 Tourism: An Introduction, Longman, UK. 